\title{
Gradients in density variations of small rodents: the importance of latitude and snow cover
}

\author{
Lennart Hansson ${ }^{1}$ and Heikki Henttonen ${ }^{2}$ \\ ${ }^{1}$ Department of Wildlife Ecology, Swedish University of Agricultural Scienes, S-750 07 Uppsala, Sweden \\ ${ }^{2}$ Department of Zoology and Kilpisjärvi Biological Station, University of Helsinki, P. Rautatiekatu 13, \\ SF-00100 Helsinki 10, Finland
}

\begin{abstract}
Summary. Microtine rodents are known to show extreme population variations (cycles) but non-cyclic populations have also been recognized during recent years. The cyclic populations have been widely thought to be regulated by intrinsic mechanisms. However, such predictions for cyclic populations are usually not applicable to non-cyclic ones and extrinsic factors may have to be included in any explanation.
\end{abstract}

A hypothesis that the degree of fluctuations in small rodent numbers is related to the sustainable number of generalist predators was tested on mainly literature data by computing "indices of cyclicity" for local populations. These indices were related to latitude and snow cover (two measures) as these variables will affect the amount of alternative prey available for these generalists. Within Fennoscandia such indices for Clethrionomys glareolus and Microtus agrestis were clearly positively related to latitude and snow cover. The fraction of populations with summer declines in numbers, characterizing highly cyclic populations, increased in the same way. Cyclicity indices in Great Britain were similar to those in southern Fennoscandia, both areas being poor in snow, but were higher at the same latitudes in eastern Europe with more snow. Indices of density variations were generally low in North American Clethrionomys species and very variable in Microtus species.

The gradients observed and differences between continents are interpreted as due to microtine-vegetation interactions in northern European areas poor in generalist predators but with important small mustelid predation, and to similar snowshoe hare-vegetation interactions in mainly Canada-Alaska, where small rodents may serve as alternative prey for numerically fluctuating hare predators, at least in the forests. Western European microtine populations, and probably many others, seem to be regulated by generalist predators.

\section{Introduction}

Small rodents frequently fluctuate in numbers and often these fluctuations are termed "cyclic" (Krebs and Myers 1974). Cyclic fluctuations, however, seldom or never show very regular amplitudes and frequencies but are characterized by a gradual increase to peak numbers and sometimes a sudden drop to very low numbers which prevail for an extended period. There are often 3-5 years between succes-

Offprint requests to: L. Hansson sive lows. However, it has recently been realized that many small rodent populations show less violent dynamics and only fluctuate seasonally in abundance (Hansson 1971; Fuller 1977; Mihok and Fuller 1982; Krebs 1979; Bashenina 1981; Jensen 1982; Taitt and Krebs 1985). Such populations have been termed non-cyclic to denote that they still may exhibit erratic density variations.

Hansson (1971, 1979 a) and Erlinge et al. (1983) argue that non-cyclic vole populations in southern Scandinavia are kept at low density and only fluctuate seasonally in numbers because of a strong functional response by generalist predators. Such predators, however, will only be effective in regions with a sustaining amount of alternative prey. The numbers and total density of alternative prey species generally decreases northwards (Simpson 1964). Density compensation in the sense of Case (1975) is hardly applicable as resources generally diminish northwards and there is no evidence of such a compensation. Generalist predators should thus be least effective in regulating microtine populations in northern Fennoscandia (for long-term data on "typical microtine cycles" in northern Fennoscandia; see Tast and Kalela 1971; Lahti et al. 1976; Henttonen et al. 1977; Hansson 1979a; Hansson et al. 1978; Laine and Henttonen 1983). Furthermore, increased snow cover is assumed to make the hunting of generalist predator species less effective in northern than in southern Fennoscandia. There are few studies of predation in relation to snow cover but e.g. great grey shrikes (Lanius excubitor) change from small mammals to birds as prey with increasing snow depth (Olsson 1984). Thus the buffering effect by generalist predators is predicted to decrease northwards and small rodent populations will increase towards food-limitation; in this area the role of specialist predators will increase at least at population declines (Hansson 1979a; Laine and Henttonen 1983).

Here we analyse this hypothesis further by examining variation in microtine population density in several geographic regions. We will concentrate on the following questions critical for the hypothesis:

1) How does the amplitude of population fluctuations increase with latitude in Fennoscandia?

2) Will variation in rodent numbers be better related to snow conditions than to latitude?

3) Will density variations in western Europe be similar to those in southern Scandinavia where the amount of snow is similar? Will density variation in eastern Europe (incl. European parts of the U.S.S.R.) be greater than at the same 
latitudes in southern Scandinavia, which would be consistent with the idea that snow makes the hunting of generalist predators less effective?

4) Will density variation in North America increase northwards and will density variations be greater in North America than those at the same latitudes in Fennoscandia where the Gulf Stream ameliorates the climate?

5) An important question would also be whether there is any threshold length of time and/or depth of snow cover related to cyclicity? We cannot, however, study this in detail because of the unpredictability of environmental conditions in the appropriate regions.

We will make our comparisons on two common and widespread European microtine species, viz. the bank vole Clethrionomys glareolus and the field vole Microtus agrestis. They are distributed from northern Fennoscandia to western and eastern Europe. They do not occur in North America but may be compared there with their taxonomical and ecological equivalents (cf. Merritt 1981; Klimkiewicz 1970) Clethrionomys gapperi and Microtus pennsylvanicus. We also compare the dynamics of two other small rodent species which occur in both northernmost Europe and northernmost North America, viz. Clethrionomys rutilus and Microtus oeconomus.

\section{Methods}

We have examined all known (to us until summer 1983) Fennoscandian trapping series covering four years or more. One reason for this lower limit is that population cycles in northern Scandinavia usually extend over four years between a population low and a subsequent peak-decline. A shorter number of years will cause great random effects in indices of cyclicity for these northern areas (cf. Henttonen et al. 1985) while three years may be enough in southern Fennoscandia and central Europe. Index trapping methods (with the index usually expressed as number caught per 100 trap nights) and density estimations have both been included. However, in density estimations only numbers actually caught have been used for our computations.

Fennoscandian island data were excluded from our analysis because the dynamics of insular rodent populations differ from those of mainland populations (e.g. Tamarin 1978; Pokki 1982). We have not made any use of sign indices (e.g. grazing frequencies) or questionnaires on vole abundance as valid, quantitative population estimates cannot be computed from such data.

We have mainly used series from outside Europe that have been published in major ecological journals. Longer series that contain discontinuities have been treated as two or more series because trapping methods or density levels may vary between subseries (e.g. Southern and Lowe 1982).

If there were continuous data in the same trapping series from two or more intermingled habitats only the data from the habitat with the highest densities were used because densities in suboptimal habitats are influenced by immigration from the optimal ones.

If there are several censuses a year we have used data from August-October as either representing annual peak numbers or showing the lowest numbers in bottom years of typically cyclic populations. This is further justified by the results of Henttonen et al. (1985) who found that cyclicity indices based on autumn densities differentiated best between cyclic and non-cyclic populations. However, in several studies only one sample has been taken each year. Such data were accepted only if repeated sampling was performed at the same time in summer-autumn.

The index

$s=\sqrt{\frac{\sum\left(\log N_{i}-\overline{\log N_{i}}\right)^{2}}{n-1}}$

where $N_{i}$ is density or a quantitative density index at the same time of the year, has been suggested as an index of density variation ("cyclicity index") that is independent of sampling method and mean density level (Lewontin 1966; Williamson 1972; Stenseth and Framstad 1980). This index was demonstrated to correlate positively with the periodicity in a large set of field data (Henttonen et al. 1985). In certain trapping series some index values equalled 0 during low years and had to be replaced by a small positive number. We used the lowest figures in the trapping series, usually 0.1 or 0.5 animals $/ 100$ trap nights. According to our experience these values are of the right order of magnitude. In addition, we also computed the coefficient of variation $(C V=\mathrm{SD} / \bar{x})$, although this index is more affected by trapping methods. Furthermore, because we feel that really cyclic microtine populations are characterized by summer declines during low years and because such declines may not be easily detected at each low phase, we also estimated the fractions of the studies in various regions in Fennoscandia which contained any clear summer decline.

In our analysis we divide Fennoscandia in three climatic, and hence biogeographic regions: (1) A southern zone (55 to about $59^{\circ} \mathrm{N}$ ) with a mild climate with little snow in winter. (2) A transition zone $\left(59-61^{\circ} \mathrm{N}\right)$ that is characterized by winters of varying snow depth and duration. (3) A zone north of $61^{\circ} \mathrm{N}$ characterized by 5-8 months of snow each year (except at the Norwegian coast) and a typical taiga forest in the lowlands and alpine tundra on the mountains. Data on local snow conditions were obtained from Johnson (1956), Ager (1964) and Solantie (1975, 1977). Two measures of snow were used: a mean annual period with snow and a mean maximum snow depth.

Data from southern Fennoscandia were compared with data from Great Britain and eastern Europe. As Great Britain extends between $50^{\circ} \mathrm{N}$ and $59^{\circ} \mathrm{N}$ the area covered in eastern Europe was likewise located between $50^{\circ} \mathrm{N}$ and $59^{\circ} \mathrm{N}$. All the Fennoscandian data are compiled in Appendix A (C. glareolus) and B (M. agrestis). Papers with information on density variations (during at least 3 years) in western and eastern Europe and North America are listed in Appendix C.

\section{Results}

\subsection{Fennoscandia}

All correlations between indices of density variations and latitude, snow cover and snow thickness were significantly positive, and of the same magnitude (Table 1). However, because latitude is strongly correlated with both the period of snow cover $(r=0.96)$ and snow thickness $(r=0.82)$, it is difficult to separate the effects of latitude (i.e. diversity and density of sustaining prey) and snow cover (i.e. predation efficiency) upon rodent population dynamics. Partial 
Table 1. Correlation matrix (Spearman's $r_{s}$ ) between environmental variables predicted to influence vole population stability and two measures ( $s$ and $C V$, see text) of population cyclicity in various Fennoscandian regions. Significance levels are ${ }^{* *}=P<0.01$ and $* * *=P<0.001$

\begin{tabular}{|c|c|c|c|}
\hline \multirow[t]{2}{*}{ Species } & \multirow{2}{*}{$\begin{array}{l}\text { Environmental } \\
\text { variables }\end{array}$} & \multicolumn{2}{|c|}{ Indices of cyclicity } \\
\hline & & $s$ & $C V$ \\
\hline $\begin{array}{l}\text { Clethrionomys } \\
\text { glareolus }\end{array}$ & $\begin{array}{l}\text { Latitude } \\
\text { Snow period } \\
\text { Maximum snow } \\
\text { thickness }\end{array}$ & $\begin{array}{l}0.62 * * * \\
0.64 * * * \\
0.65 * * *\end{array}$ & $\begin{array}{l}0.63 * * * \\
0.68 * * * \\
0.70 * * *\end{array}$ \\
\hline $\begin{array}{l}\text { Microtus } \\
\text { agrestis }\end{array}$ & $\begin{array}{l}\text { Latitude } \\
\text { Snow period } \\
\text { Maximum snow } \\
\text { thickness }\end{array}$ & $\begin{array}{l}0.61 * * * \\
0.60 * * * \\
0.57 * *\end{array}$ & $\begin{array}{l}0.67 * * * \\
0.64 * * * \\
0.65 * * *\end{array}$ \\
\hline
\end{tabular}

Table 2. Mean values for the cyclicity indexes and distribution of summer declines observed in trapping series in various Fennoscandian regions

\begin{tabular}{|c|c|c|c|c|c|}
\hline \multirow[t]{2}{*}{ Species } & \multirow[t]{2}{*}{ Latitude } & \multicolumn{2}{|c|}{$\begin{array}{l}\text { Mean } \\
\text { cyclicity index }\end{array}$} & \multicolumn{2}{|c|}{$\begin{array}{l}\text { Summer } \\
\text { decline }\end{array}$} \\
\hline & & $\bar{s}$ & $\bar{C} \bar{V}$ & No & Yes \\
\hline $\begin{array}{l}\text { Clethrionomys } \\
\text { glareolus }\end{array}$ & $\begin{array}{rl}<59^{\circ} \mathrm{N} & 59-61^{\circ} \mathrm{N} \\
> & 61^{\circ} \mathrm{N}\end{array}$ & $\begin{array}{l}0.22 \\
0.47 \\
0.52\end{array}$ & $\begin{array}{l}0.44 \\
0.78 \\
0.92\end{array}$ & $\begin{array}{l}6 \\
4 \\
4\end{array}$ & $\begin{array}{r}1 \\
3 \\
13\end{array}$ \\
\hline $\begin{array}{l}\text { Microtus } \\
\text { agrestis }\end{array}$ & $\begin{aligned}< & 59^{\circ} \mathrm{N} \\
& 59-61^{\circ} \mathrm{N} \\
> & 61^{\circ} \mathrm{N}\end{aligned}$ & $\begin{array}{l}0.30 \\
0.53 \\
0.62\end{array}$ & $\begin{array}{l}0.61 \\
0.97 \\
1.14\end{array}$ & $\begin{array}{l}6 \\
2 \\
1\end{array}$ & $\begin{array}{l}0 \\
6 \\
9\end{array}$ \\
\hline
\end{tabular}

correlations become very low due to the high correlations between latitude and the two snow variables. They were highest between $C$. glareolus indices and snow thickness $\left(r_{k}=0.41\right)$ and between $M$. agrestis indices and latitude $\left(r_{k}=\right.$ 0.32 ). However, we can mainly state that the cyclicity increased with both latitude and snow cover.

The mean cyclicity values increased from the southern region over the transition zone to the northern region ( $\mathrm{Ta}$ ble 2). That the increase from the southern region to the transition zone was greater in both species than from the transition zone to the northern taiga implies that there may be a "cyclicity threshold" bordering the transition zone. This is also reflected in the proportion of summer declines (Table 2) in intense studies with both spring and autumn trappings. There were clear differences between the southern zone and the northern taiga zone for both $C$. glareolus ( $P=0.009$, Fisher's exact probability test) and $M$. agrestis $(P=0.001)$. The transition zone did not deviate significantly from either of the other zones, except from the southern zone for $M$. agrestis $(P=0.009)$. If the data from the transition zone are added either to those from the southern zone or the northern taiga zone, then the difference in relation to either the north or south remains significant for both species ( $P$ 's $0.01-0.02$, except for $M$. agrestis when the transition zone is added to northern taiga; $P=0.006$ ). These patterns imply that the transition zone is really intermediate, or may have more in common with the northern taiga zone than with the southern zone.

\subsection{Western and eastern Europe}

Southern Scandinavian C. glareolus did not show any significantly different pattern in density variation from British populations (Mann-Whitney U-test). Mean s and CV values for the southern Scandinavian populations $(N=7)$ were 0.22 and 0.44 and in Great Britain $(N=10) 0.28$ and 0.51 , respectively. However, the British populations were very heterogeneous and at least one showed a summer decline. Two German studies (Schmidt 1975; Stubbe 1982) showed $s=0.29$ and $0.40(\mathrm{CV}=0.55$ and 0.76$)$. Comparisons between southern Scandinavia and the same latitudes in eastern Europe (Poland and U.S.S.R. west of the Urals, $N=28$ ) resulted in significant differences (Mann-Whitney $U=51$ and 48.5 respectively, $P<0.05$ ) for both $s$ and $C V$ with most pronounced density variation in eastern Europe (mean $s=0.31$ and mean $C V=0.65$ ). Separate calculations were performed with data from southern Scandinavia and the European part of the U.S.S.R. only with the thicker snow cover, but the differences and levels of significance remained the same.

Population data for $M$, agrestis were available only from western Europe. Five series from Great Britain did not differ from southern Scandinavia $(N=8)$. The mean values of $s$ were 0.32 and 0.30 and of $C V 0.64$ and 0.61 for Great Britain and southern Scandinavia, respectively. The first study at Lake Vyrnwy (Chitty 1952) showed pronounced cyclicity $(s=0.95)$ and a summer decline while later studies (Chitty 1962) indicated only seasonal variations ( $s=$ 0.16 and 0.25 ). Thus, as with $C$. glareolus, some British $M$. agrestis populations exhibited pronounced density variations. Some German $M$. agrestis populations showed small density variations (Kulicke 1956, $s=0.25$; Schindler 1972, $s=0.35$ ).

\subsection{North America}

Four population of $C$. gapperi from the U.S.A. had mean $s$ values of 0.38 and thirteen populations from Canada had 0.42 ( $C V=0.73$ and 0.92 ). There was no correlation with latitude. No 3-4 year cyclic pattern was observed (cf. also Merritt 1981) but in long term studies by Grant (1976) and Fuller (1977) series of high and low density years were separated by about 10 years. Krebs and Gilbert (1984) also found a 10-year interval between peaks in C. rutilus. Furthermore, according to available information (West 1982; Whitney and Feist 1984) C. rutilus, the northern equivalent of $C$. gapperi, is not 3-4 year cyclic in central Alaska near Fairbanks at those latitudes where both $C$. glareolus and C. rutilus are strongly 3-4 year cyclic in northern Fennoscandia. The $s$ and CV values for $C$. rutilus in Alaska were 0.11 and 0.20 , and 0.26 and 0.51 respectively (West 1982 ; Whitney and Feist 1984), which correspond to the low southern Scandinavian values for $C$. glareolus. At about the same latitudes in northern Finland and Sweden the $s$ and $\mathrm{CV}$ values for C. glareolus were $0.56-0.89$ and $0.80-2.05$ respectively. Values for $C$. rutilus were there of the some order.

Most studies of American Microtus populations have been conducted south of $50^{\circ} \mathrm{N}$ (Taitt and Krebs 1985) and are thus not strictly comparable with the northern European ones. Taitt and Krebs (1985) divided the fluctuation patterns observed in North America into cyclic and annual ones. $48 \%$ of the years studied showed multiannual cyclic patterns in $M$. pennsylvanicus according to the definition 
of cyclicity by these authors. In other Microtus species this proportion was even lower (e.g. $M$. townsendii Bachm.: $29 \%$ ). A long-term study (11 years) of $M$. pennsylvanicus in southern Canada (Mihok $1985,50^{\circ} \mathrm{N}$ ) had $s=0.48$, which is similar to central Fennoscandian $M$. agrestis. A shortterm study of $M$. oeconomus populations at Fairbanks, Alaska (Whitney $1976,65^{\circ} \mathrm{N}$ ) gave $s=0.75$ while longer studies (17 years) of the same species at Kilpisjärvi, Finnish Lapland (Tast and Kalela 1971; Henttonen et al. 1977; Fig. 2B) resulted in $s=0.82$ ( $C V=1.31$ and 1.26 respectively). In this respect $M$. oeconomus in central Alaskan taiga resembles conspecifics in northern Fennoscandia. The amplitude (peak/low in cyclic populations) in the American studies was generally about tenfold (Taitt and Krebs 1985) while in northern Fennoscandia it has often been 100 -fold or more.

\section{Discussion}

We find the clear Fennoscandian correlations with both latitude and snow cover convincing, although data used in the analysis were obtained by several different trapping methods. The $C V$ index of cyclicity gave consistently better correlations than the $s$ index, so the variability in the data acquisition did not seem to influence the results in any profound way. Correlations might have been still better but the northernmost records in Fennoscandia were from the margins of the distribution of $C$. glareolus and M. agrestis and there their abundance, and especially peak numbers, will be affected by interspecific competition from other small rodents (Henttonen and Hansson 1984). M. agrestis, for example, is forced into marginal habitats by $M$. oeconomus (Tast 1968; Henttonen et al. 1977) and consequently the northernmost cyclicity index for $M$. agrestis was fairly low. Environmental heterogeneity in the transition zone is another error. The snowy period is relatively short but variable, and snow cover is shallow along the shores of the Baltic, especially far into the mainland in SW Finland.

One explanation of the gradients in cyclicity in Fennoscandia could be differences in predator-prey relationships. The effective element in the hypothesis of population regulation by predation is a set of alternative prey species for generalist predators. These alternative prey may be sustained by various means, e.g., little snow, a considerable proportion of agricultural land (Angelstam et al. 1984) or diverse habitats (or landscape heterogeneity, Hansson 1977, $1979 \mathrm{~b}$ ). Most such conditions are negatively related to the severity of the environment. An alternative explanation of the trend in cyclicity in Fennoscandia can be based on the relations between rodents and variations in plant productivity and quality (e.g. Laine and Henttonen 1983). However, the present data do not permit us to separate between these hypotheses. Laine and Henttonen (1983) and Hansson (1984a) discuss reasons why the decline in northern Fennoscandia is probably triggered by changes in food resources. But if microtines in northern Fennoscandia followed only the rhythms of their food plant species, for example, which are in fairly good but not in total synchrony, more interspecific variation in the decline should be expected among sympatric microtine species due to specific feeding preferences. Instead, all sympatric microtine species (up to 8 species in a community) in northern Fennoscandia have the deepest low phase simultaneously (Hansson 1969; Tast and Kalela 1971; Henttonen et al. 1977; Hansson et al. 1978; Laine and Henttonen 1983; Henttonen in prep.), a fact consistent with the role of specialist predators (small mustelids, cf. also Oksanen and Oksanen 1981; Hansson 1984b; Henttonen 1985). The cyclic synchrony of sympatric microtines decreases southwards, and in the transition zone sympatric $C$. glareolus and $M$. agrestis may or may not be in phase (Korpimäki 1981; Pankakoski 1984; Hansson in prep.). In any case, we discuss our data further without denying any effect of possible multiannual variation in plant production on microtine cycles.

Stable populations of microtines in southern Fennoscandia and central Europe appear to be controlled by generalist predators (Hansson 1979 a; Erlinge et al. 1983), and during seasonal lows of voles these predators are supported by alternative prey. C. glareolus is generally adapted to mature forest habitats with a more complex fauna of predators and alternative prey, while Microtus spp. are colonists of disturbed areas and early successional plant communities with a less complex fauna. Southern Microtus populations may therefore be more likely to show cyclic behaviour than corresponding Clethrionomys populations. There were some clearly cyclic microtine populations also in western Europe. One example is the early $M$. agrestis population at Lake Vyrnwy which later seemed to change to a non-cyclic one (Chitty 1952; Chitty and Chitty 1962). This change followed an alteration in the landscape from a vast area with abandoned fields and conifer seedlings to diverse forest habitats interspersed with open fields. The predator and alternative prey community might have showed a pronounced development during this landscape transition. Other areas in central Europe with cyclic populations may be characterized by similar conditions, e.g. large agricultural areas in Poland harbouring cyclic Microtus arvalis populations (Ryszkowski et al. 1973).

There has been a long-lasting debate whether factors intrinsic (e.g. physiological stress or genetic behavioural polymorphism) or extrinsic (e.g. food and predation) to microtine populations cause the cyclicity (e.g. Krebs and Myers 1974). The clear relationship between the level of cyclicity and environmental conditions in Fennoscandia seems to demonstrate the overriding importance of extrinsic factors. Gradients in cyclicity can hardly be explained by any intrinsic factors. On the other hand, microtine populations, also at southern latitudes, have obviously the potential to become cyclic if environmental conditions (habitat structure, fauna, quality of seasonality) permit (Chitty 1952; Ryszkowski et al. 1973).

Non-cyclic (or "annual") population variations have been observed in several North American Clethrionomys and Microtus species. Merritt (1981) states that "there seem to be no 3-4 year oscillation in C. gapperi". This also appears to apply to C. rutilus in northern Canada and Alaska. No geographical trend in cyclicity has been observed in North American Microtus species (Taitt and Krebs 1985) but such a trend has been reported for snowshoe hares Lepus americanus (Wolff 1980). Thus, there seems to be a basic difference in microtine dynamics between Fennoscandia and North America.

One possible explanation is that in northern North America the small (forest) rodents are alternative prey for the predators driven by the pronounced snowshoe hare cycles. Then a 10-year periodicity should be expected in Clethrionomys in areas with snowshoe hare cycles, but only annual changes with stable hare or rabbit populations. If so, 
more than one alternative mechanism could be possible. 1) Generalist predators might increase during the hare increase phase until the peak, but will suddenly lose the greatest part of their food basis during the first years of the hare decline. During these years there should be severe pressure on small rodents but the latter cannot be supposed to sustain these predators for any longer period. Thus, a few years after the start of the hare decline, predation pressure should have lessened considerably and the small rodents will be free to increase considerably in numbers. Specialist predators need a certain period of high small rodent numbers in order to reproduce and increase, and a rodent peak may appear before hares and generalist predators increase again. 2) Another alternative is that predation on abundant hares releases the pressure from forest microtines, but in this case Clethrionomys peaks should coincide with the hare peak and earliest decline, and Clethrionomys should decline with hares. 3) Yet another possibility is that predation by generalist predators on small specialist ones at the end of the hare decline will release a Clethrionomys increase, and specialist predators would recover after the decline of the generalists. In this case a Clethrionomys peak should also occur a few years after the hare peak.

Some data to test these ideas are available. High Clethrionomys numbers were found a few years after hare peaks by Fuller (1977 and pers. comm.) in Canadian NW Territories, and by Krebs and Gilbert (1984 and pers. comm.) in southern Yukon. Such conditions seem also evident in unpublished data supplied by Mihok (pers. comm.) from Manitoba. Grant (1976) concluded that peaks in the abundance of C. gapperi occurred at 10-year intervals in Quebec, as they do in the snowshow hare. These data seem to refute the second alternative. The third alternative assumes considerably densities of specialist predators, but at least in some Clethrionomys study areas, pygmy weasels, for instance, are rare (Fuller pers. comm.; Krebs and Gilbert pers. comm.). So with the few data available we find the first alternative most plausible.

There is also another difference between Fennoscandian and North American vertebrate communities, which might stabilize small rodents dynamics in the latter area. Various species of hibernating ground squirrels and chipmunks not found in Fennoscandia could sustain predators that would otherwise prey on microtines in summer. Extreme summer declines of the north Fennoscandian type might be prevented this way.

We suggest that the driving force in the $3-5$ year cycles in central and northern Fennoscandia is a microtine-food interaction (Kalela 1962; Hansson 1969, 1979a; Tast and Kalela 1971; Laine and Henttonen 1983). In northern Fennoscandia all predators preying on microtines decline after a microtine crash (Pulliainen 1981; Kaikusalo 1982) due to shortage of alternative food, and consequently predators exhibit a time lag in their response to the microtine increase. Also the pattern of game population dynamics, including the mountain hare Lepus timidus, in central and northern Fennoscandia seems to be a 3-5 year cycle (Hörnfeldt 1978; Pulliainen 1982; Angelstam et al. 1984). Bulmer (1974, 1975) concluded statistically that the driving force in the North American 10-year furbearer cycle is the snowshoe hare, and several authors have suggested that this cycle is caused by an interaction between the hare and its food (Keith 1974, 1983; Keith et al. 1984; Bryant 1981) that is modified by predators (Keith 1974). In this comparison between northern North America and Fennoscandia some species are especially interesting. The muskrat Ondatra $z i$ bethicus in North America shows a 10-year pattern (Elton and Nicholson 1942; Bulmer 1974, 1975), but as an introduced species in Europe has, in northern Sweden, a 4-year rhythm which seems to be caused by predation by red foxes after microtine declines (Danell 1978). In spite of its preference for microtines the American marten in the boreal zone is in phase with the snowshoe hare (Bulmer 1975). The red fox is another generalist hunting both microtines and hares, and its cycle clearly follows that of hares (Bulmer 1975). In central and northern Fennoscandia the red fox and pine marten have 3-4 year cycles (Pulliainen 1981; Kaikusalo 1982; Angelstam et al. 1984).

In this context we would also draw attention to the differences in the quality and quantity of snow between northern North America, and central and northern Fennoscandia. Over large areas of boreal North America the winter climate is continental, resulting in a powder-like soft snow cover, which in many areas is not very thick. On the other hand, warm spells are common in the more maritime Fennoscandian winter; the thick snow cover is dense and often encrusted. These differences probably also influence the hunting success of generalist predators. Differences in the thickness of snow cover in North America are not, however, large enough to cause clear differences in the fluctuation pattern of Clethrionomys, since the few study areas with very thick snow cover (Weckwerth and Hawley 1962; Merritt 1978) have annual patterns similar to regions with less snow.

The increasing stability of microtine populations towards southern, more diverse, biotic communities fits well with the old paradigm, "diversity begets stability", being forcefully contradicted during recent years (e.g. May 1973; Goodman 1975; Pimm 1982). However, in the present context a "sub-community" consisting of generalist predators and several abundant alternative prey species (obviously from different taxonomic and ecological groups, e.g. microtines, hares and squirrels) is considered to cause stability and no relationship is assumed to the total biotic community. An equally large sub-community of many specialist predators and one main prey species or species group (e.g. microtines) is predicted to cause instability. Thus, the quality and not the quantity of species constituting an interacting unit seems to be important for the numerical stability of separate species populations. 


\section{Appendix A}

Cyclicity indexes of Clethrionomys glareolus in Fennoscandia

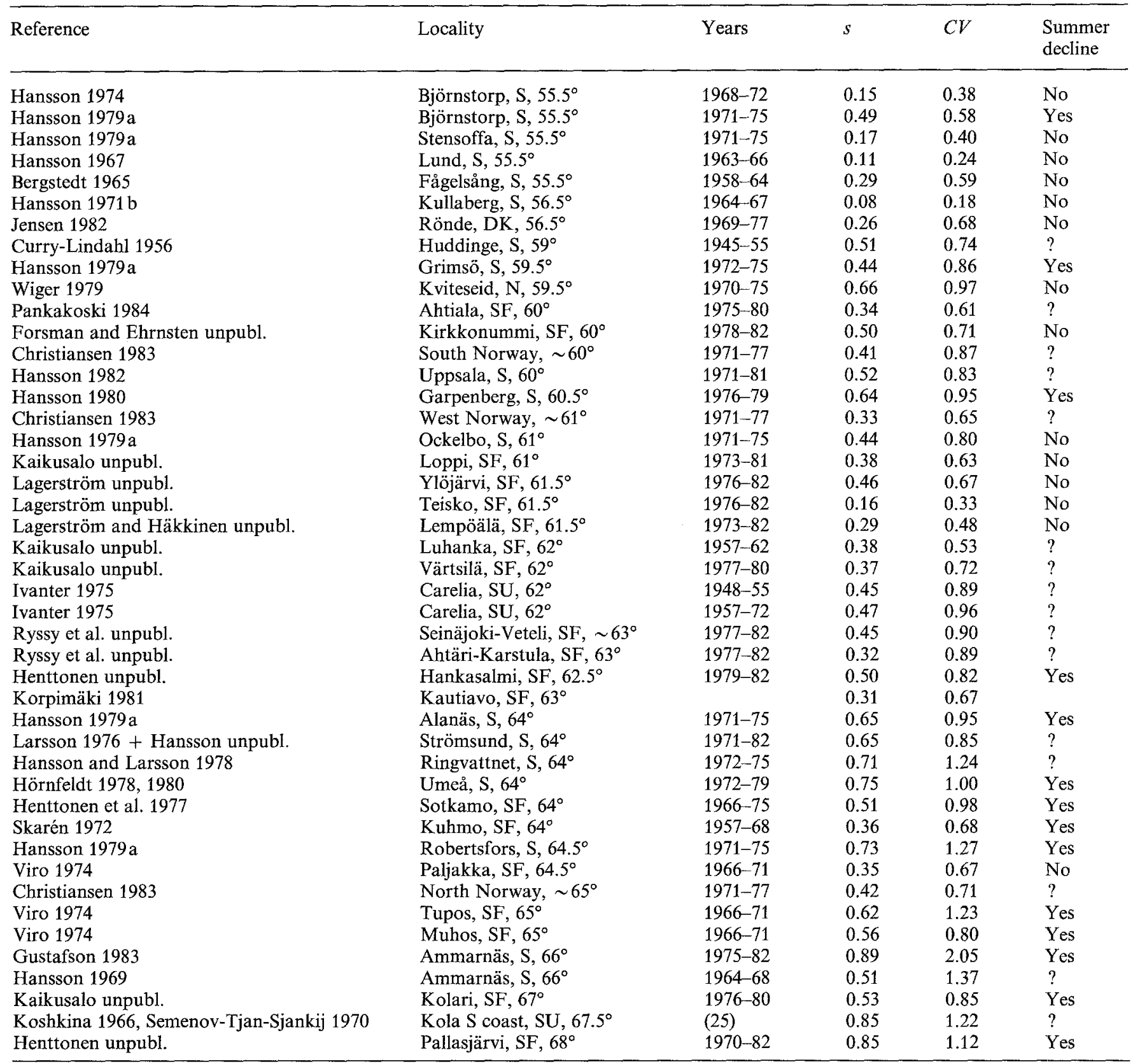

\section{Appendix B}

Cyclicity indexes of Microtus agrestis in Fennoscandia

\begin{tabular}{|c|c|c|c|c|c|}
\hline Reference & Locality & Years & $s$ & $C V$ & $\begin{array}{l}\text { Summer } \\
\text { decline }\end{array}$ \\
\hline Hansson 1974 & Björnstorp, S, 55.5 & $1968-72$ & 0.22 & 0.39 & No \\
\hline Hansson unpubl. & Stensoffa, $S, 55.5^{\circ}$ & $1971-80$ & 0.18 & 0.39 & No \\
\hline Erlinge et al. 1983 & Revinge, $S, 55.5^{\circ}$ & $1974-77$ & 0.49 & 0.77 & No \\
\hline Hansson $1971 \mathrm{a}$ & Sjötorp, $\mathrm{S}, 55,5^{\circ}$ & $1964-70$ & 0.28 & 0.51 & No \\
\hline Hansson $1971 \mathrm{a}$ & Kullaberg, S, 56.5 & $1964-68$ & 0.31 & 0.50 & No \\
\hline Curry-Lindahl 1956 & Huddinge, $S, 59^{\circ}$ & $1945-55$ & 0.37 & 0.71 & $?$ \\
\hline
\end{tabular}


Appendix B (continued)

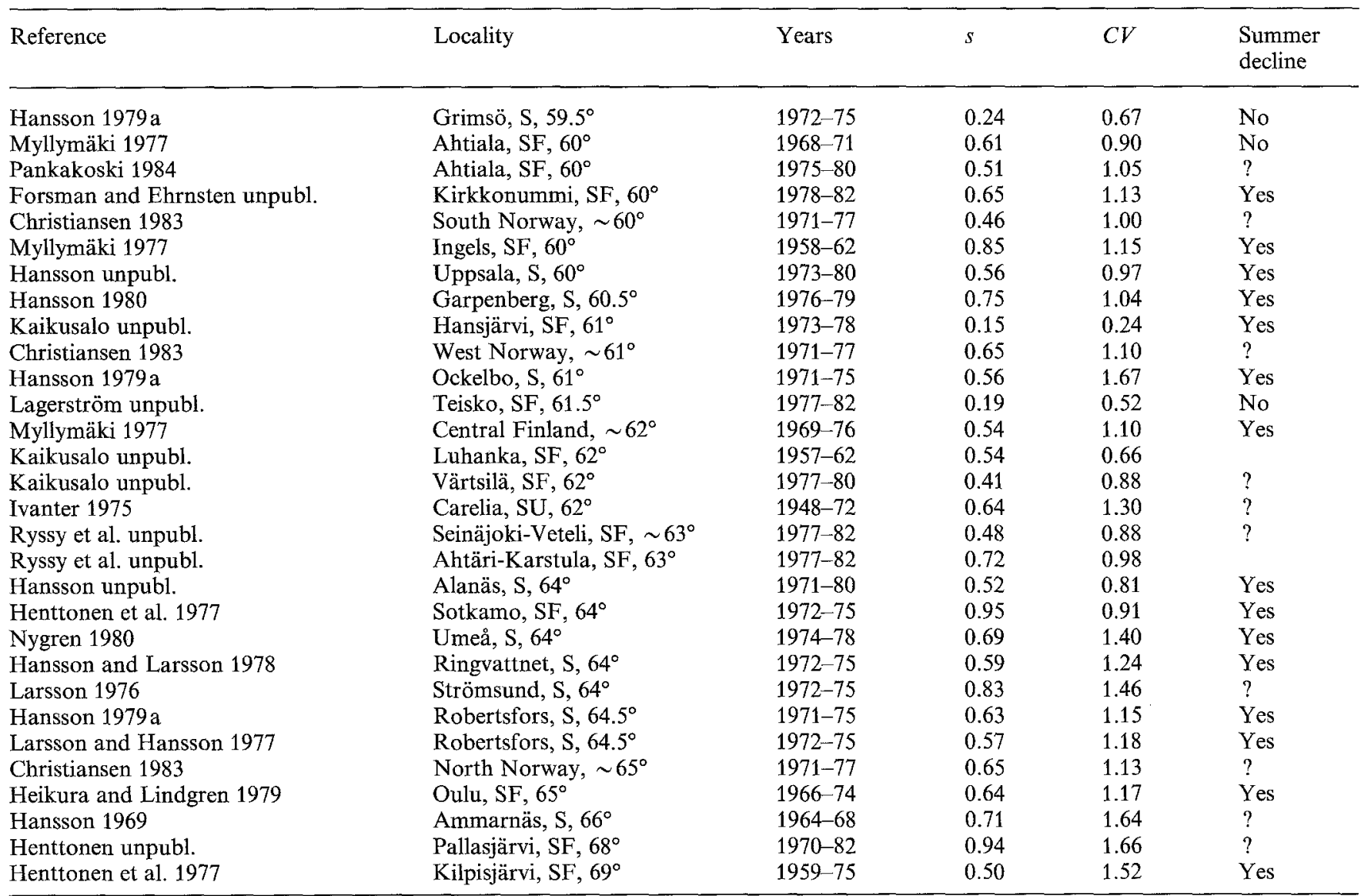

\section{Appendix C}

Literature data on small rodent fluctuation patterns outside Fennoscandia

Great Britain: Ashby 1966; Brown 1964; Chitty 1952; Chitty and Chitty 1962; Flowerdew and Gardner 1978; Jewell 1966; Montgomery 1979; Newson 1963; Smyth 1968; Southern and Lowe 1982; Tanton 1969.

East Europe (only Clethrionomys glareolus): Andrzejewski 1975; Bobek 1973; Grodzinski et al. 1970 and Ryszkowski 1971 for Poland and a compilation of many papers from U.S.S.R. in Bashenina (1981).

North America: Mainly literature cited by Merritt (1981) on Clethrionomys gapperi and by Taitt and Krebs (1983) on Microtus spp.

Acknowledgements. Our joint work was supported by a grant from the Nordic Council of Ecology. The study was made while HH enjoyed an Emil Aaltonen Scholarship, and a part of the final phase during HH's Fulbright Scholarship at the Inst. Arctic Biol., Univ. Alaska in Fairbanks. We thank Per Angelstam, John Bryant, Dennis Chitty, Sam Erlinge, Dale Feist, Erkki Haukioja, Olli Järvinen, Erik Lindström and Lauri Oksanen for comments on the manuscript.

\section{References}

Ager BH (1964) Studies of the climate in North and Central Sweden. Studia Forest. Suecica 19, 105 pp

Andrzejewski A (1975) Supplementary food and winter dynamics of bank vole populations. Acta Theriol 20:23-40

Angelstam P, Lindström E, Widén P (1984) Role of predation in short-term population fluctuations of some birds and mammals in Fennoscandia. Oecologia (Berlin) 62:199-208
Ashby KK (1967) Studies on the ecology of field mice and voles (Apodemus sylvaticus, Clethrionomys glareolus and Microtus agrestis) in Houghall Wood, Durham. J Zool Lond $152: 389-513$

Bashenina NV (1981) The European bank vole. Nauka, Moscow

Bergstedt B (1965) Distribution, reproduction, growth and dynamics of the rodent species Clethrionomys glareolus (Schreber), Apodemus flavicollis (Melchior) and Apodemus sylvaticus (Linné) in south Sweden. Oikos 16:132-161

Bobek B (1973) Net productivity of small rodents in a deciduous forest. Acta Theriol 18:403-434

Brown LE (1954) Small mammal populations at Silwood Park Field Centre, Berkshire, England. J Mammal 35:161-176

Bryant JP (1981) Phytochemical deterrence of snowshoe hare browsing by adventitious shoots of four Alaskan trees. Science 213:889-890

Bulmer MG (1974) A statistical analysis of the 10-year cycle in Canada. J Anim Ecol 43:701-718

Bulmer MG (1975) Phase relations in the ten-year cycle. J Anim Ecol 44:609-621

Case TJ (1975) Species number, density compensation and the colonization ability of lizards in the Gulf of California. Ecology $56: 3-8$

Chitty D (1952) Mortality among voles (Microtus agrestis) at Lake Vyrnwy, Montgomeryshire, in 1936-9. Phil Trans Roy Soc London Ser B 236:505-552

Chitty D, Chitty H (1962) Population trends among voles at Lake Vyrnwy, 1932-60. Symposium Theriologicum, Brno, pp 67-76

Christensen JT (1978) Habitat selection of Microtus at the Tippere peninsula. Natura Jutland 20:163-172

Christiansen E (1983) Fluctuations in some small rodent populations in Norway 1971-1979. Holarct Ecol 6:24-31

Curry-Lindahl K (1956) Biotoper, revir, vandringar och periodicitet hos några smådäggdjur. Fauna o Flora 51:193-218 
Danell K (1978) Population dynamics of the muskrat in a shallow Swedish lake. J Anim Ecol 47:697-710

Dolbeer RA, Clark WR (1975) Population ecology of snowshoe hares in Central Rocky Mountains. J Wildl Manage 39:535-549

Elton C, Nicholson M (1942) The ten-year cycle in numbers of the lynx in Canada. J Anim Ecol 11:215-244

Erlinge S, Göransson G, Hansson L, Högstedt G, Liberg O, Nilsson IN, Nilsson T, von Schantz T, Sylvén M (1983) Predation as a regulating factor on small rodent populations in southern Sweden. Oikos 40:36-52

Flowerdew JR, Gardner G (1978) Small rodent populations and food supply in a Derbyshire ashwood. J Anim Ecol 47:725-740

Fuller WA (1977) Demography of a subarctic population of Clethrionomys gapperi: numbers and survival. Can J Zool 55:42 51

Goodman D (1975) The theory of diversity-stability relationships in ecology. Quart Rev Biol 50:237-266

Grant PR (1976) An eleven year study of small mammal populations at Mont St-Hilaire, Quebec, Canada. Can J Zool 54:2156-2173

Grodzinski W, Bobek B, Drozdz A, Gorecki A (1970) Energy flow through small rodent populations in a beech forest. In: Petrusewicz K, Ryszkowski L (eds) Energy flow through small mammal populations. Warsaw, pp 291-298

Gustafsson T (1983) Reproduction and social regulation of sexual maturation in relation to cyclicity in bank voles, Clethrionomys glareolus. Thesis, Lund

Hansson L (1967) Population densities of small rodents in forest habitats in south Sweden in 1963-66. Acta Univ Lund Sect II, No $12,12 \mathrm{pp}$

Hansson L (1969) Spring populations of small mammals in central Swedish Lapland in 1964-68. Oikos 20:431-450

Hansson L (1971 a) Habitat, food and population dynamics of the field vole Microtus agrestis (L.) in south Sweden. Viltrevy $8: 267-378$

Hansson L (1971b) Small rodent food, feeding and population dynamics. A comparison between granivorous and herbivorous species in Scandinavia. Oikos 22:183-198

Hansson L (1974) Small mammal productivity and consumption in spruce forest and reforestation in south Sweden. Oikos $25: 153-156$

Hansson L (1977) Landscape ecology and stability of populations. Landscape Plann 4:85-93

Hansson L (1979a) Food as a limiting factor for small rodent numbers: Tests of two hypotheses. Oecologia (Berlin) $37: 297-314$

Hansson L (1979b) On the importance of landscape heterogeneity in northern region for the breeding population densities of homeotherms: A general hypothesis. Oikos 33:182-189

Hansson L (1980) Surplus areas for voles on forest regenerations and their importance for the vole damage. Rapp Inst Viltekol $3,48 \mathrm{pp}$

Hansson L (1982) Use of forest edges by Swedish mammals. Fauna o. Flora $77: 301-308$

Hansson L (1984a) Composition of cyclic and non-cyclic vole populations: On the causes of variation in individual quality among Clethrionomys glareolus in Sweden. Oecologia (Berlin) 63:199-206

Hansson L (1984b) Predation as the factor causing extended low densities in microtine cycles. Oikos 43:255-256

Hansson L, Larsson T-B (1978) Vole diet on experimentally managed reforestation areas in northern Sweden. Holarct Ecol $1: 16-26$

Hansson L, Löfquist J, Nilsson A (1978) Population fluctuations in insectivores and small rodents in northernmost Fennoscandia. Z Säugetierk 43:75-92

Heikura K, Lindgren I (1979) Reproduction in the field vole, $\mathrm{Mi}^{-}$ crotus agrestis L., in the vicinity of Oulu, Finland. Aquilo Ser Zool 19:33-43

Henttonen H (1985) Predation causing extended low densities in microtine cycles: Further evidence from shrew dynamics. Oikos: in press

Henttonen H, Hansson L (1984) Interspecific relations between small rodents in European boreal and subarctic environments. Acta Zool Fennica 172:61-65

Henttonen H, Kaikusalo A, Tast J, Viitala J (1977) Interspecific competition between small rodents in subarctic and boreal ecosystems. Oikos $29: 581-590$

Henttonen H, McGuire AD, Hansson L (1985) Comparisons of amplitudes and spectral analyses of density variations in longterm data sets of Clethrionomys species. Ann Zool Fennici: in press

Hörnfeldt B (1978) Syncronous population fluctuations in voles, small game, owls and tularemia in northern Sweden. Oecologia (Berlin) 32:141-152

Hörnfeldt B (1980) Antal fångade ängssorkar i Västerbotten. Monitor 1980:77-79

Ivanter EV (1975) Population ecology of small mammals in the north-western taiga of the U.S.S.R. Nauka, Moscow

Jensen TS (1982) Seed production and outbreaks of non-cyclic rodent populations in deciduous forests. Oecologia (Berlin) 54:184-192

Jewell PA (1966) Breeding season and recruitment in some British mammals confined on small islands. Symp Zool Soc London $15: 89-116$

Johnson B (1956) Studier över vinterklimatet i södra och mellersta Sverige. Sver Skogsv förb Tidskr 54:395-409

Kaikusalo A (1982) Predatory mammals and vole populations in the fell regions of north-west Finland. Suomen Riista 29:89-92

Kalela $O$ (1962) On the fluctuations in the numbers of arctic and boreal small rodents as a problem of production biology. Ann Acad Sci Fenn A IV 66:1-38

Keith KB (1974) Some features of population dynamics in mammals. Proc Int Congr Game Biol 11:17-58

Keith KB (1983) Role of food in hare population cycles. Oikos 40:385-395

Keith LN, Cary JR, Rongstad OJ, Brittingham MC (1984) Demography and ecology of a declining snowshoe hare population. Wildl Monogr 90:1-43

Klimkiewicz MK (1970) The taxonomic status of the nominal species Microtus pennsylvanicus and Microtus agrestis (Rodentia: Cricetidae). Mammalia 34:640-665

Korpimäki E (1981) On the ecology and biology of Tengmalm's Owl (Aegolius funereus) in southern Ostrobothnia and SuomenSelkä, Western Finland. Acta Univ Ouluensis, Ser A Sci Rer Nat 118, Biol 13:1-84

Koshkina TV (1966) On the periodical changes in numbers of voles: An example from the Kola peninsula. Bull Mosc Soc Nat $71: 14-26$

Krebs CJ (1979) Dispersal, spacing behaviour and genetics in relation to population fluctuations in the vole Microtus townsendii. Fortschr Zool 25:61-77

Krebs CJ, Gilbert BS (1984) Population dynamics of Clethrionomys rutilus in the southern Yukon, Canada. Symp Ecol Bank voles and Wood mice, Abstr. p 24

Krebs CJ, Myers JH (1974) Population cycles in small mammals. Adv Ecol Res 8:267-399

Kulicke H (1956) Untersuchung über Verbreitung, Auftreten, Biologie und Populationsentwicklung der Erdmaus (Microtus agrestis L.) in den Jahren 1952-1955. Arch Forstw 5:820-835

Lahti S, Tast J, Uotila H (1976) Fluctuations in small rodent populations in the Kilpisjärvi area in 1950-1975. Luonnon Tutkija $80: 95-107$

Laine K, Henttonen $H$ (1983) The role of plant production in microtine cycles in northern Fennoscandia. Oikos 40:407-418

Larsson T-B (1976) Small rodent population and damage in forest regenerations. Thesis, Stockholm

Larsson T-B, Hansson L (1977) Vole diet on experimentally managed afforestation areas in northern Sweden. Oikos 28:242-249

Lewontin RC (1966) On the measurement of relative variability. Syst Zool 15:141-142 
Martell AM (1983) Changes in small mammal communities after logging in north-central Ontario. Can J Zool 61:970-980

May RM (1973) Stability and complexity in model exosystems. Princeton Univ Press, Princeton, NJ

Merritt JF (1981) Clethrionomys gapperi. Mammalian Species 146, $9 \mathrm{pp}$

Mihok S, Fuller WA (1981) Morphometric variation in Clethrionomys gapperi: Are all voles created equal? Can J Zool 59:2275-2283

Mihok S, Turner BN, Iversen SL (1985) The characterization of vole demography. Ecol Monogr: in press

Montgomery WT (1979) Seasonal variation in numbers of Apodemus sylvaticus, A. flavicollis and Clethrionomys glareolus. J Zool Lond 188:283-286

Myllymäki A (1977) Demographic mechanisms in the fluctuating populations of the field vole Microtus agrestis. Oikos 29:468-493

Newson R (1963) Difference in number, reproduction and survival between two neighbouring populations of bank voles (Clethrionomys glareolus). Ecology 44:110-120

Nygren J (1980) Genetic variation in allozymes and behaviour in field vole populations and its implications of demographic changes. Thesis, Umeå

Oksanen L, Oksanen T (1981) Lemmings (Lemmus lemmus) and grey-sided voles (Clethrionomys rufocanus) in interaction with their resources and predators on Finnmarksvidda, northern Norway. Rep Kevo Subarctic Stat 17:7-31

Olsson V (1984) The winter habits of the great grey shrike Lanius excubitor. II Territory. Vår Fågelvärld 43:199-210

Pankakoski E (1985) Relationship between meterological factors and population dynamics of Sorex araneus L. in southern Finland. Acta Zool Fennica (in press)

Pimm SL (1982) Food webs. Chapman and Hall, London

Pokki J (1981) Distribution, demography and dispersal of the field vole, Microtus agresis (L.), in the Tvärminne archipelago, Finland. Acta Zool Fennica 164:1-48

Pulliainen E (1981) A transect survey of small land carnivores and red fox populations on a subarctic fell in Finnish Forest Lapland over 13 winters. Ann Zool Fennici 18:270-278

Pulliainen E (1982) Habitat selection and fluctuations in numbers in a population of the arctic hare Lepus timidus on a subarctic fell in Finnish Forest Lapland. Z Säugetierk 47:168-174

Ryszkowski L (1971) Reproduction of bank voles and survival of juveniles in different pine forest ecosystems. Ann Zool Fennici 8:85-91

Ryszkowski L, Goszcynski J, Truszkowski J (1973) Trophic relationships of the common vole in cultivated fields. Acta Theriol 18:125-165

Schindler U (1972) Massenwechsel der Erdmaus (Microtus agrestis L.) in Süd-Niedersachsen 1952-71. Z Angew Zool 59:189-203

Schmidt A (1975) Populationsdynamik und Ökologie der terrestrischen Kleinsäuger des Naturschutzgebietes Schwarzberge. Naturschutzarbeit Berlin u Brandenburg 11:78-92

Semenov-Tjan-Sjankij O (1970) Population cycles in red-backed voles. Bull Mosc Soc Nat 75:25-26

Simpson GG (1964) Species density of North American recent mammals. Syst Zool 13:57--73
Skarén UAP (1972) Fluctuations in small mammal populations in mossy forests of Kuhmo, eastern Finland, during eleven years. Ann Zool Fennici 9:147-151

Smyth M (1968) The effect of the removal of individuals from a population of bank voles Clethrionomys glareolus. I Anim Ecol 37:167-183

Solantie R (1975) The areal distribution of winter precipitation and snow depth in March in Finland. Ilmat Lait Tied 28, 66 $\mathrm{pp}$

Solantie R (1977) On the persistence of snow cover in Finland. Ilmat Lait Tutkim 60,68 pp

Southern HN, Lowe VPN (1982) Predation by tawny owls (Stric aluco) on bank voles (Clethrionomys glareolus) and wood mice (Apodemus sylvaticus). J Zool Lond 198:83-102

Stenseth NC, Framstad E (1980) Reproductive effort and optimal reproductive rates in small rodents. Oikos $34: 23-34$

Stubbe M (1982) Dynamik der Kleinnagergesellschaft (Rodentia: Arvicolidae, Muridae) in Hakel. Hercynia NF 19:110-120

Taitt MJ, Krebs CJ (1985) Population dynamics and cycles. In: Tamarin RH (ed) Biology of new world microtines (in press)

Tamarin RH (1978) Dispersal, population regulation and K-selection in field mice. Am Nat 112:545-555

Tanton MT (1969) The estimation and biology of populations of the bank vole (Clethrionomys glareolus Schr.) and the wood mouse (Apodemus sylvaticus L.). J Anim Ecol 38:511-530

Tast J (1968) Influence of the root vole, Microtus oeconomus (Pallas) upon the habitat selection of the field vole, Microtus agrestis (L.), in northern Finland. Ann Acad Sci Fenn Ser A IV, Biol 136, 23 pp

Tast J, Kalela O (1971) Comparison between rodent cycles and plant production in Finnish Lapland. Ann Acad Sci Fenn Ser A IV, Biol 186, 14 pp

Viro P (1974) Age structure in populations of the bank vole, Clethrionomys glareolus (Schreb 1790) in northern Finland. Aquilo Ser Zool 15:18-24

Wagner FH (1981) Role of lagomorphs in ecosystems. Proc World Lagomorph Conf 1:668-694

Weckworth RP, Hawley VD (1962) Marten food habits and population fluctuations in Montana. J Wildl Manage 26:55-74

West SD (1982) The dynamics of colonization and abundance in central Alaskan populations of the northern red-backed vole, Clethrionomys rutilus. J Mammal 63:128-143

Wiger R (1979) Demography of a cyclic population of the bank vole Clethrionomys glareolus. Oikos 33:373-385

Whitney P (1976) Population ecology of two sympatric species of subarctic microtine rodents. Ecol Monogr 46:85-104

Whitney P, Feist D (1984) Abundance and survival of Clethrionomys rutilus in relation to snow cover in a forested habitat near College, Alaska. Spec Publ Carnegie Mus Nat Hist 10:113-119

Williamson M (1972) The analysis of biological populations. Arnold, London

Wolff JO (1980) The role of habitat patchiness in the population dynamics of snowshoe hares. Ecol Monogr 50:111-130

Received January 31, 1985 